\title{
Mustafa Kemal Paşa Tarafindan Ali Fuad Paşaya Gönderilen Bazı Telgraf, Tebliğ ve Yazışmalar-(I)*
}

\author{
Mustafa TOKER ${ }^{* *}$
}

Mondros Mütarekesi (30 Ekim 1918) imzalandıktan sonra İtilaf devletlerinin Mütarekenin 7. maddesi doğrultusunda Türk topraklarını işgale başlaması üzerine ülkede bölgesel direniş hareketleri başlamıştır. Önceleri bölgesel nitelik taşıyan direniş, Mustafa Kemal'in Anadolu'ya geçmesi ile örgütlü hale getirilmiş ve ulusal bir mücadeleye dönüşmüştür. Mustafa Kemal, Samsun'a çıkmadan önce Makedonya'dan başlayarak birlikte hareket ettikleri subaylardan oluşan çekirdek kadro ile (Rauf (Orbay), Ali Fethi (Okyar), Kazım Karabekir, Ali Fuat (Cebesoy), İsmet (İnönü)) devletin içinde bulunduğu durumdan kurtulması konusunda görüşmeler yapmış ve son çözüm olarak Anadolu'ya geçilmesi gerektiğine karar vermiştir.

Mustafa Kemal Anadolu'ya geçtikten sonra en büyük desteği Erzurum'da 15. Kolordu Komutanı Kazım Karabekir ve Ankara'daki 20. Kolordu Komutanı Ali Fuat Paşadan almıştır. Mustafa Kemal'in Anadolu'daki faaliyetlerini aydınlatması açısından, her iki kolordu komutanı ile yapılan görüşmeler son derece önemlidir.

Türk İnkılap Tarihi Enstitüsü Arşivinde bulunan ve Ali Fuat Cebesoy'a ait koleksiyon içerisinde yer alan Mustafa Kemal Paşaya ait bazı telgraf, tebliğ ve yazışmaları içeren belgeler de aynı döneme ait önemli bilgileri içermektedir. Bu koleksiyonda bulunan belgelerin bir kısmı bu çalışmada yer almaktadır. Çalışmada yer alan belgeler genel olarak:

Kongre murahhaslarının yola çıkması; Mustafa Kemal'in milli bağımsızlık için tüm mevcudiyetiyle çalışacağına dair söz vermesi; Rumeli'ye ait şifrelerin Dersaadet'te kontrol edildiğinden şüphelenildiği; Erzurum'da Kazım Karabekir ile yapılan görüşme sonucunda dahili vaziyetin iyi olduğu; Bolşeviklik ve Kafkasya ile ilgili bilgiler; Kongrede

- Mustafa Kemal Paşa tarafından Ali Fuad Paşa'ya gönderilen telgraf, tebliğ ve yazışmaların ikinci bölümü derginin izleyen sayısında yayımlanacaktır.

"*Ankara Üniversitesi Türk İnkılâp Tarihi Enstitüsü Uzmanı. 
seçilen heyet; Karesi'deki 14. Kolordu Komutanı Yusuf İzzet Paşa ile yapılan görüşmenin güvenli olup olmadığı; Cemal Paşa ve Yusuf İzzet Paşa ile ilgili bilgiler; Ali Kemal ve Konya Valisi Cemal Bey ve Gümülcineli İsmail Beylerin pek iyi niyetlerinin olmadığı; Dersaadet raporu hakkındaki yorumları; İslam çetelerinin tamamen geri çektirildiğini ve Hristiyan ahaliye emniyet sağlandığı; Rumların da çetelerini şehirlere indirmeğe söz verdiği; gerek Erzurum ve gerekse Canik'te bulunan İtilaf devletleri temsilcilerine Hristiyanların İslam ahaliye içeride ve dışarıda yaptıkları mezalimler hakkında haberdar edildikleri; Dersaadet'teki Fransız İstihbarat Şubesinin Anadolu'daki milli harekatın sebeplerini ve bunun başkentle olan ilişkilerinin belirlemeye çalıştıkları; bunun için kendilerine bilgi verilmemesi gerektiği; para meselesi ve Konya'nın durumu hakkında bilgi beklendiği; Ali Fuat Cebesoy'un babası ile tanışması; Milli Mücadele düşmanlarına karşı kesin bir icraat zamanın geldiği; Kayseri ahalisinin hükümetin aleyhinde olduğu; mebus seçimlerinin hızlandırılması ile ilgili bir tebligatın yapılmadığ 1 ; Konya Valisi Cemal Beyin bazı serserilerden jandarma kaydettiği; milli harekatın adi bir eşkiyalıktan ibaret olduğu şeklinde yalanlar söylediği; Ferit Paşa kabinesini düşürülmesi için tedbir alınması, haberleşmenin hala kesik bulunduğu; hıyanetleri belli olan memurlara daha ne gibi bir baskı uygulanabileceği konularını içermektedir. 
Belgeler:

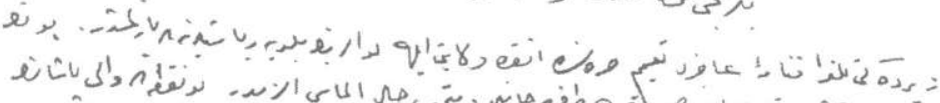

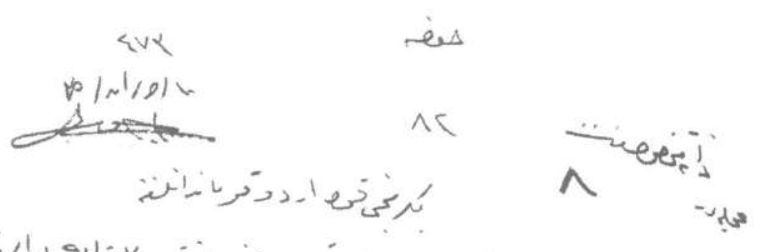

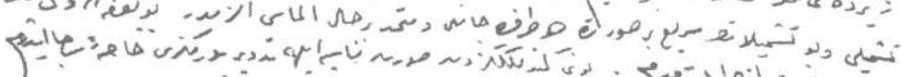

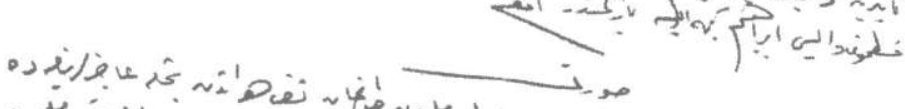

य و

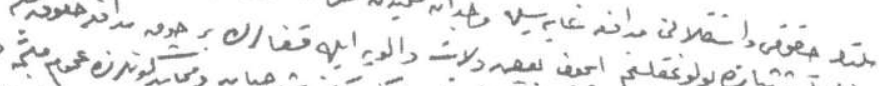

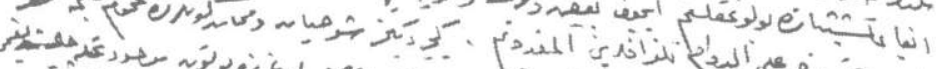

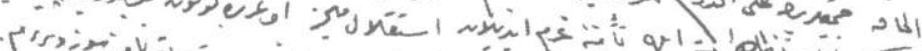

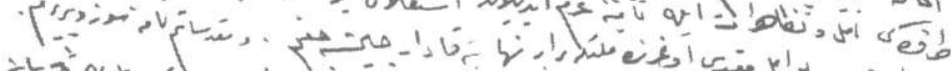

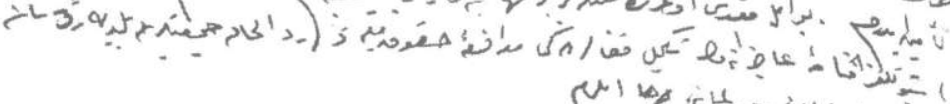

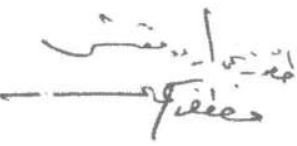
(N)

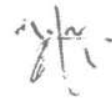


Zâta Mahsûsdur

Aceledir
Mahreci:Havza

Numrosu:82

Telgrâfhâne Numrosu: 473

Târîh-i Vürûdu:10 Hazirân 35

\section{Yirminci Kolordu Kumandanlı̆̆ına}

Zîrdeki telgrâfnâme-i 'acizî ta'mîm sirasında Ankara Vilâyetî ile livâlarının belediye riyâsetlerine de yazılmışdır. Bunun teşmîli ve bu teşmîlâtın serî̀ bir sûrette her tarafda canlı müttehid bir hal alması elzemdir. Bu noktada vâlî pâşânın te sîrine mürâca'at etmek istemedim. Bunun kendiliğinizden sûret-i münâsebe ile tedvîr buyurmanızı hâssetsen ricâ ederim.

Kastamonu Vâlîsi İbrâhîm Beye ise yazılmışdır efendim.

\section{Sûret}

Milletin hukûku ve istiklâlini müdâfa'a gâyesiyle vicdân-ı millîden doğan tezâhürâtdan bahisle 'âcizlerinin de îfâ-yı teşebbüsâtda bulunmaklığım için ba'z vilâyet ve elviye ile kazâların bir çok müdâfa'a-i hukûk-ı milliye ve redd-i ilhâk cem iyetlerinin âlîü'd-devâm telgrâflarını almakdayım. Geçirdiğimiz şu hayat ve memât günlerinde 'umûm milletçe her tarafdaki emel ve tezâhürât ile te'mînine 'azm edilen istiklâl-i millîmiz uğrunda bütün mevcûdiyetimle çalışdı̆̆ımı tèmîn ederim. Bu emel-i mukaddes uğrunda milletle berâber nihâyete kadar çalışacağım. Ve mukaddesâtım nâmına söz veririm. İşbû telgrâfnâme-i 'âcizânemin tekmîl kazâlardaki müdâfa'a-i hukûk-ı milliye ve redd-i ilhâk cem'iyetleriyle belediye rü'esâsına kadar serî̀ân îblâg buyrulmasını ricâ eylerim.

İstihbârât

'Aded 82

Dokuzuncu Ordu Müfettiş̂̂

Mustafâ Kemâl ${ }^{l}$

' TITE Arşivi, Kutu No: 295, Gömlek No: 4, Belge No: 4. 
MUSTAFA KEMAL PAŞA TARAFINDAN ALI FUAD PAŞAYA..... 221

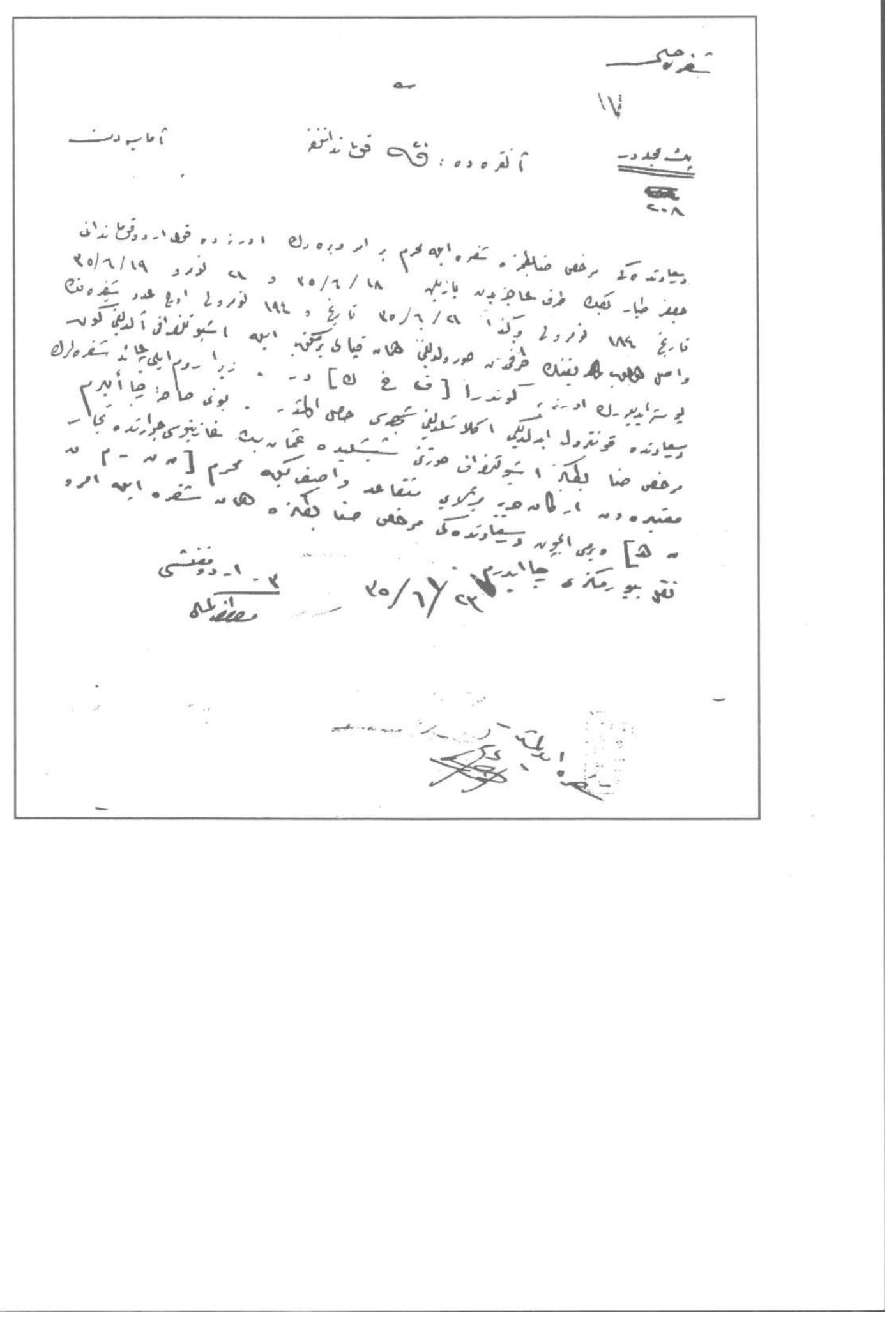


Şifre hâlli

Pek 'Aceledir/208

Amasya'dan

Ankara'da: 20. K. Kumandanlı̆̆ına

Dersa'âdet'deki murahhas zâbitimize şifre ile mahrem bir emir vererek Edirne'de Kolordu Kumandanı Ca'fer Tayyâr Beyin taraf-ı 'aciziden yazılan 18/6/1335 ve 21 numro 19/6/1335 târîh 184 numrolu ve kezâ 21/6/1335 târîh ve 194 numrolu üç 'aded şifrenin vâsıl olup olmadığının tarafımdan sorulduğunu hemân kapalı bir mektûb ile işbû telgrâfı aldığım gün posta edilerek Edirne'ye, gönderir alf $h$ k] dir. Zîrâ Rûmeli'ye 'â'id şifrelerin Dersa'âdet'de kontrol edildiği anlaşıldı̆̆ı şüphesi olmuşdur. Bunu hâsseten ricâ eylerim. Murahhas zâbitiniz işbû telgrâf sûretini Şişli'de 'Osmân Bey Gâzînosu civârında tüccâr mu'tebereden Erkân-l Harbiye Mîrâlâyı Mütekâ'id Vâsıf Beye mahrem [ $n n r m k n h$ ] vermesi için Dersa'âdet'deki murahhas zâbitinize hemân şifre ile emr ve nakil buyurmanızı ricâ ederim.

\section{$23 / 6 / 35$}

Şifre edilmişdir.

3. Ordu Müfettişî

Mustafâ Kemâl

\footnotetext{
${ }^{2}$ TITE Arşivi, Kutu No: 295, Gömlek No: 20, Belge No: 20.
} 
MUSTAFA KEMAL PAŞA TARAFINDAN ALI FUAD PAŞAYA...$\quad 223$

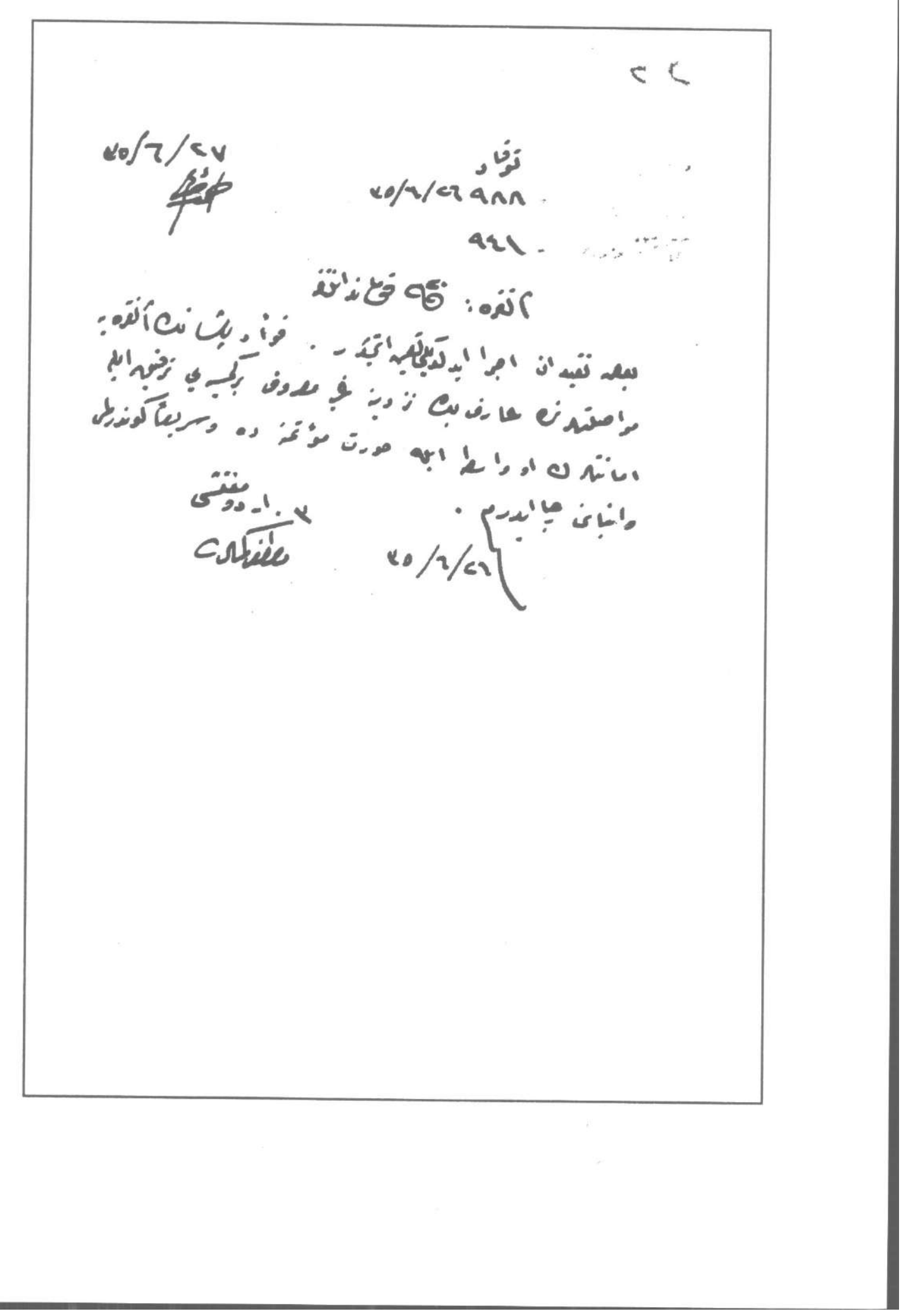


Tokad

$27 / 6 / 35$

$98826 / 6 / 35$

941

Ankara: 20. K. Kumandanlığına

Ba'zı takayyüdât icrâ edildiği ta'yîn etmişdir. Fû'âd Pâşânın Ankara'ya muvâsalatlarında 'Ârif Bey nezdîne gayr-ı ma'ruf bir kimseyi terfík ile emânetlerin o vâsıta ile sûret-i mǜ temennede ve serî́ân gönderilmesi ve inbâsını ricâ ederim. 26/6/35

3. Ordu Müfettişî

Mustafâ Kemâl ${ }^{3}$

${ }^{3}$ TİTE Arşivi, Kutu No: 295, Gömlek No: 22, Belge No: 22. 


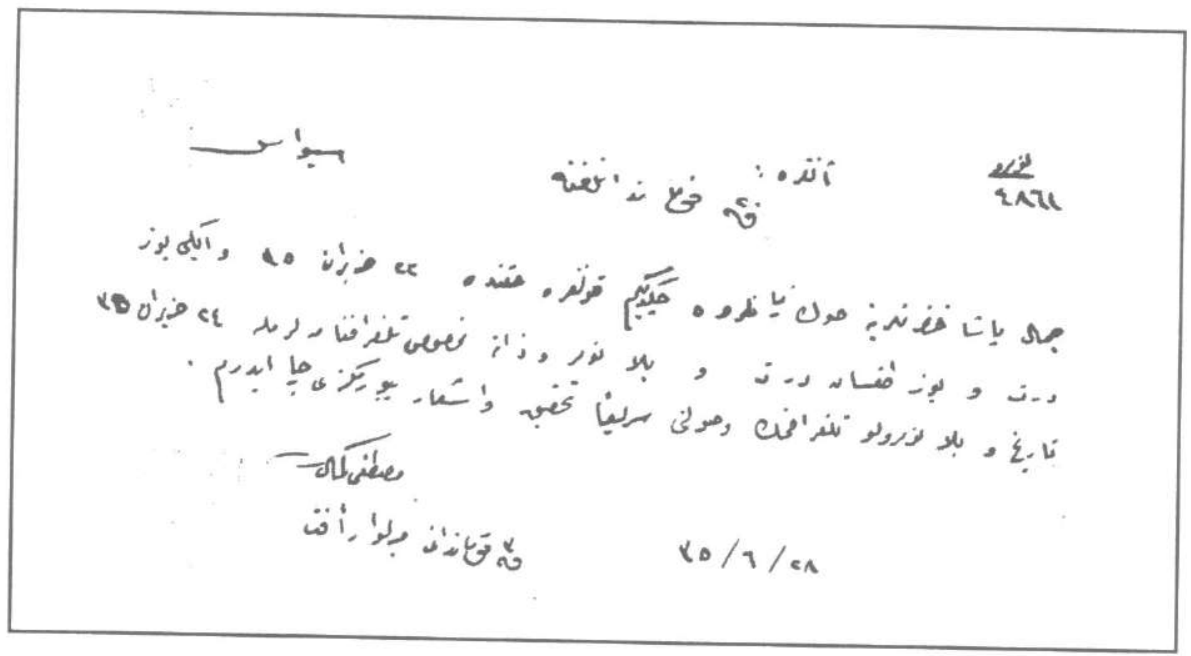


Numro/4861

Sivâs

Ankara: 20. K. Kumandanlığına

Cemâl Pâşâ Hazretlerine son zamânlarda çektiğim kongre hakkında 22 Hazîrân 35 ve 204 ve 194 ve bilâ numro ve zâta mahsûs telgrâfnâmelerimle 24 Hazîrân 35 târîh ve bilâ numrolu telgrâfimın vusûlünü serî'ân tahkîk ve işâr buyurmanızı ricâ ederim.

$28 / 6 / 35$

\author{
Mustafâ Kemâl \\ 3. K. Kumandanı
}

Mîrlivâ $\operatorname{Re}^{`} f t^{4}$

${ }^{4}$ TITE Arşivi, Kutu No: 295, Gömlek No: 33, Belge No: 33. 


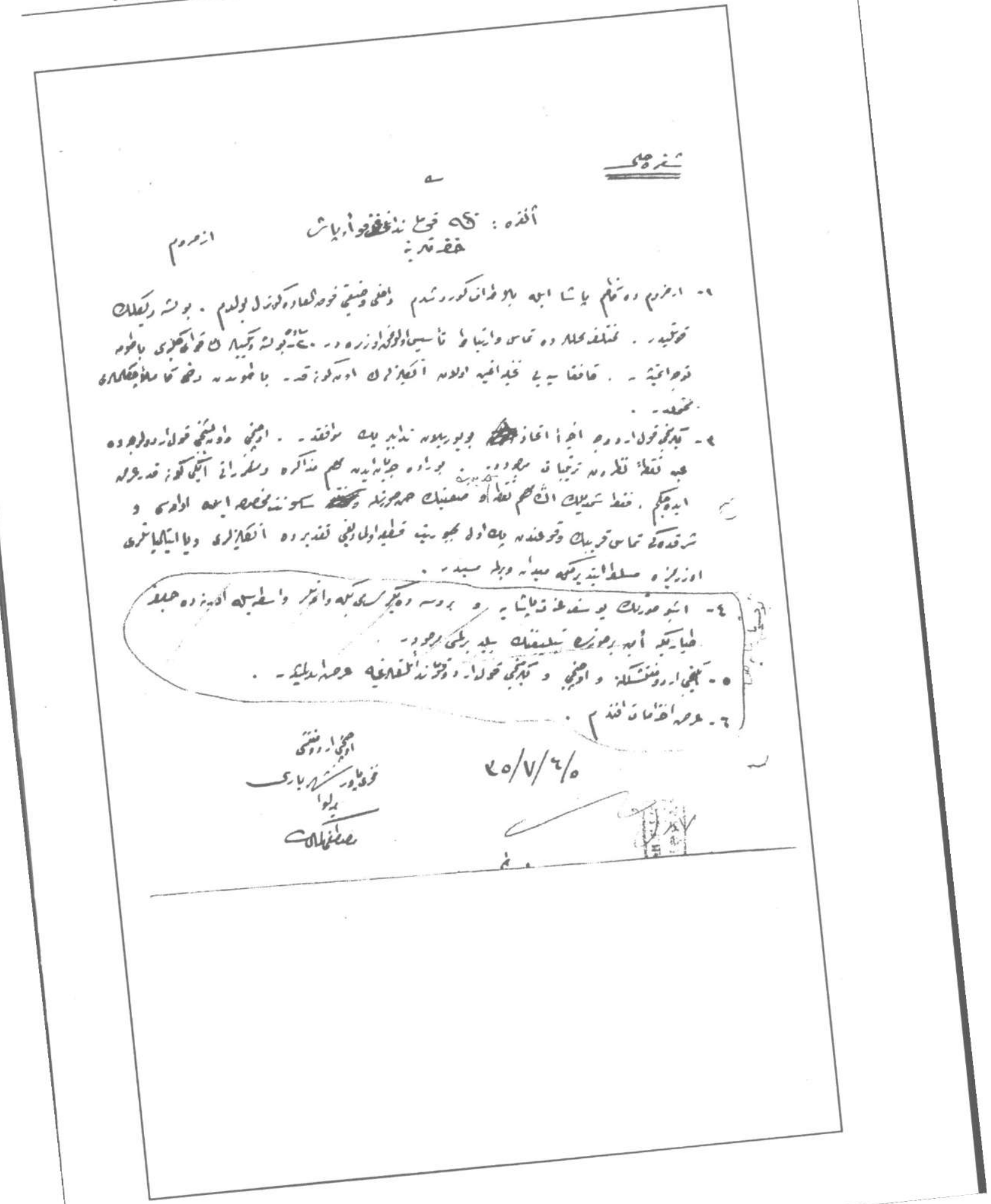


Şifre hâlli/Zâta mahsûsdur

Erzurum

Ankara: 20. K. Kumandanı 'Alî Fû̀ âd Pâşâ Hazretlerine

1-Erzurum'da Kâzım Pâşâ ile bilâ-taraf görüşdüm. Dâhili vaz'iyeti fevka'l'âde güzel buldum. Bolşevîklik kuvvetlidir. Muhtelif mahallerde temâs ve irtîbât te`sîs olunmak üzeredir.

2-Bolşevîkilerin kuvâ-yı külliyesi Batum'a teveccüh etmişdir. Kafkasya'yt tahliye etmiş olan Ingilizlerin on güne kadar Batum'dan dahî kâmilen çekilmeleri muhtemeldir.

3-Yirminci Kolorduca âhîren ittihâz buyrulan tedâbîr pek muvâfikdır. Üçüncü ve Onbeşinci Kolordularca da 'aynı nokta-i nazardan tertibât mevcûddur. Burada cereyân eden mühim müzâkere ve mukarrerâtı iki güne kadar 'arz edeceğim. Fakat şimdilik en mühim nokta ve vaz'iyetin hüsn-i sûretle ve sükûnet-i mahsûsa ile idâmesi ve şarkdaki temâs-ı karîbîn vukû́undan pek evvel mecbûriyet-i kat'iye olmadı̆̆ı takdîrde İngilizleri veyâ İtalyanları üzerimize musallat ettirmeğe meydân verilmemesidir.

4-İşbû sûretin Yûsuf 'İzzet Pâşâya ve Bursa'da Bekîr Sâmî Beye ve onlar vâsıtasıyla Edirne'de Ca'fer Tayyâr Beye emîn bir sûrette teblî̆ginin bildirilmesi mercûdur.

5-İkinci Ordu Müfettişliğine ve Üçüncü ve Yirminci Kolordu Kumandanlıklarına 'arz edilmiştir.

6-'Arz-ı ihtirâmât efendim.

4-5/7/35 Vürûdu 6 minh 3:30 sonra

Üçüncü Ordu Müfettişî Fahrî Yâver-i Şehr-yârî

Mîrlivâ Mustafâ Kemâl

\footnotetext{
${ }^{5}$ TITTE Arşivi, Kutu No: 295, Gömlek No: 46, Belge No: 46 .
} 


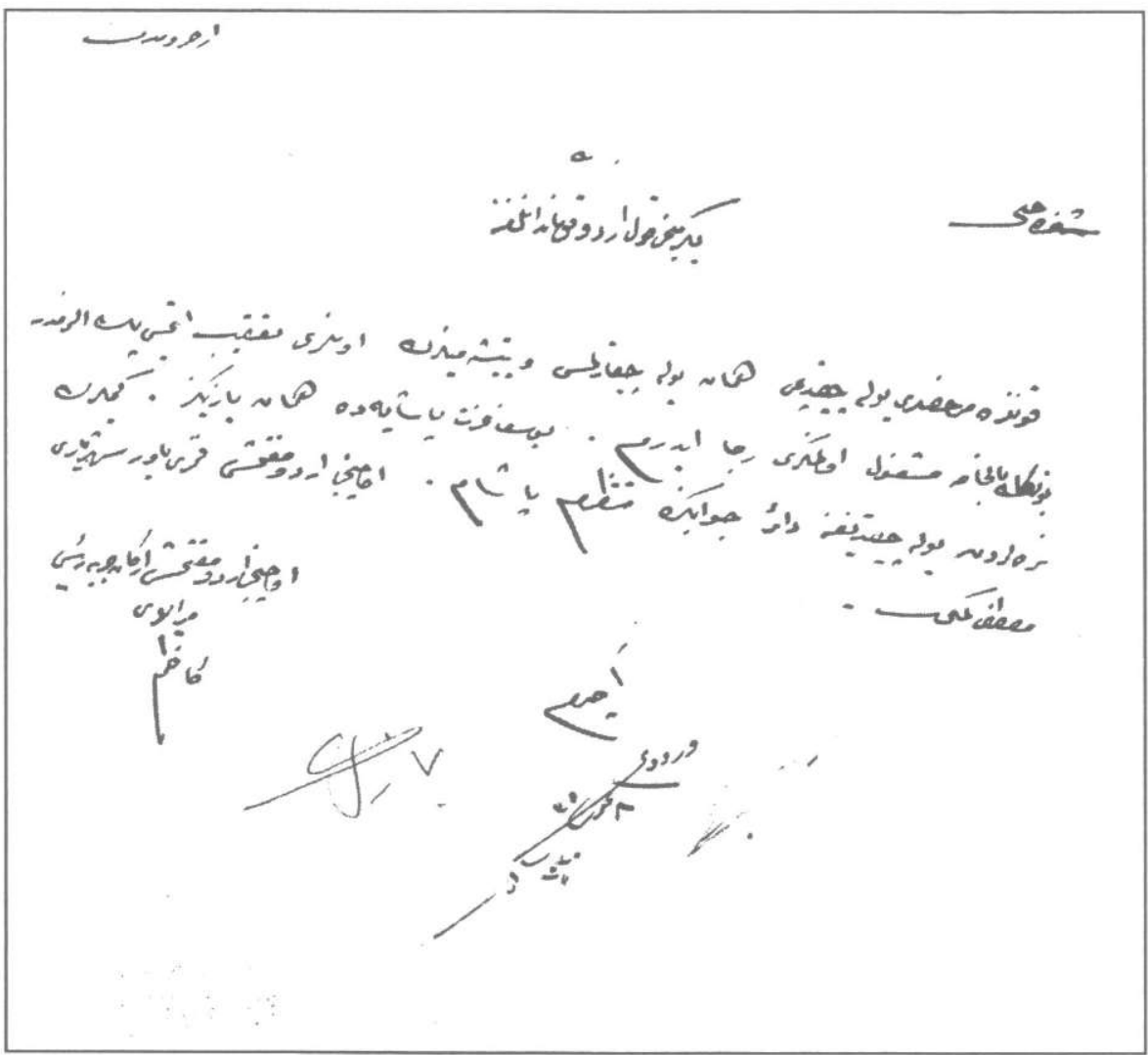


Şifre hâlli

Erzurum

20. K. Kumandanlığına

Kongre murahhasları yola çıktı mı? Hemân yola çıkarılması ve yetişemeyenlerin onları ta'kîb etmesi pek elzemdir. Bununla bilhâssa meşgul olmanızı ricâ ederim. Yûsuf 'İzzet Pâşâya da hemân yazınız. Kimlerin nerelerden yola çıkdı̆̆ına dầ ir cevâbınıza muntazırım pâşâm.

U̧̧̧üncü Ordu Müfettişî Fahrî Yâver-i Şehr-yârî

Mustafâ Kemâl

Açdım vürûdu 8 Temmuz 35

Saat 10:30

U̧̧̧üncü Ordu Müfettişî Erkân-ı Harbiye Re 'îsi

Mîrâlây Kâzım ${ }^{6}$

${ }^{6}$ TITTE Arşivi, Kutu No: 296, Gömlek No: 11, Belge No: 11. 
MUSTAFA KEMAL PAŞA TARAFINDAN ALI FUAD PAŞAYA..... 231

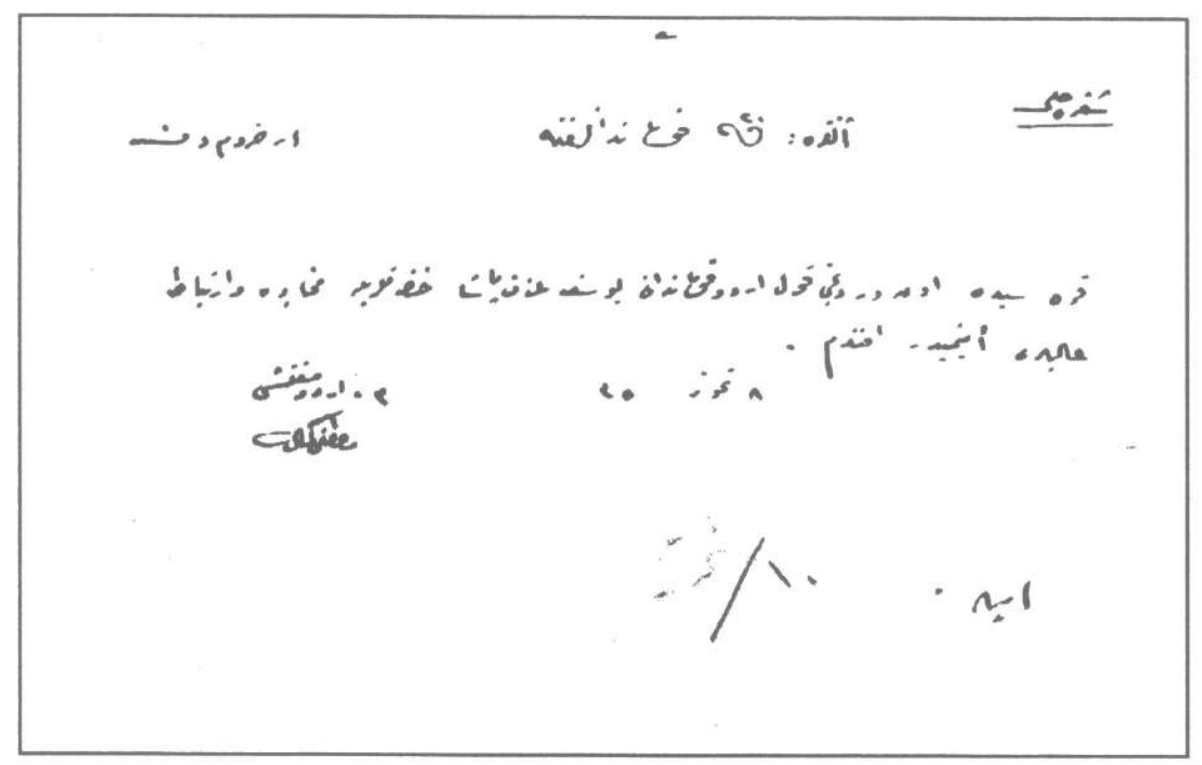


Şifre hâlli

Erzurum'dan

Ankara: 20. K. Kumandanlı̆̆ına

Karesî'de Ondördüncü Kolordu Kumandanı Yûsuf 'İzzet Pâşâ Hazretleriyle muhâbere ve irtîbât- $l$ 'alîleri emîn midir efendim?

8 Temmûz 35

3. Ordu Müfettişî

Mustafâ Kemâl

${ }^{7}$ TiTE Arşivi, Kutu No: 296, Gömlek No: 19, Belge No: 19. 


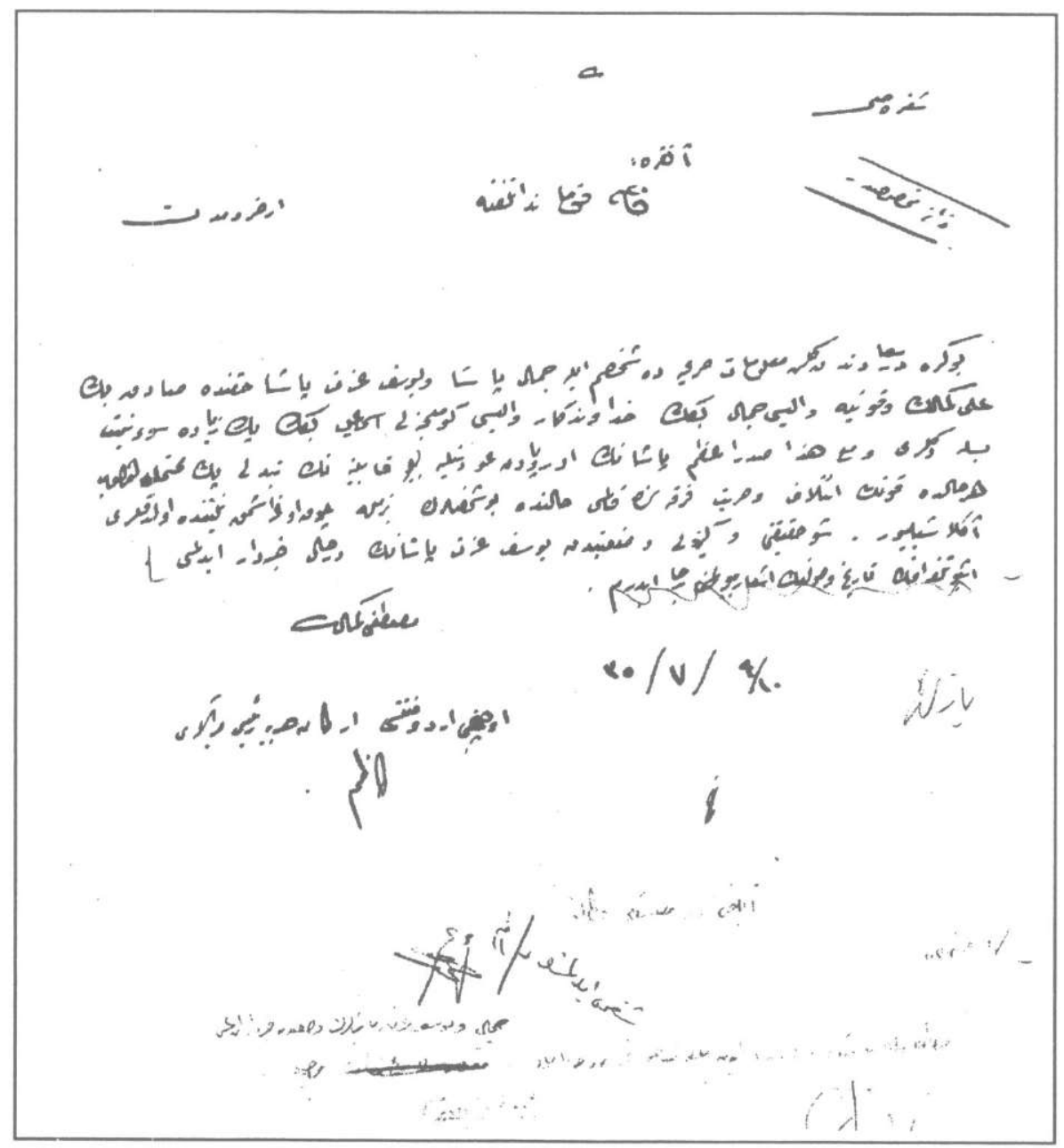


Ankara: 20. K. Kumandanlı̆̆ına

Bu kere Dersa'âdet'ten gelen ma'lûmât-ı sarîha da şahsım ile Cemâl Pâşâ ve Yûsuf 'Izzet Pâşâ hakkında Sâdık Bey 'Alî Kemâl'in ve Konya Vâlîsi Cemâl Beyin Hüdâvendigâr Vâlîsi Gümülcineli İsmâ'îl Beyin pek ziyâde sû-i niyet besledikleri ve ma'-hazâ sadr-ı â'zam pâşânin Avrupa'dan 'avdetiyle bu kâbînenin tebeddülü pek muhtemel olup her hâlde kuvvetin I'tilâf ve Hürriyet Fırkası'nda kalması hâlinde bu şahısların bizimle çok uğraşmak niyetinde oldukları anlaşılıyor. Şu hakîkati ve gizli vaz 'iyetden Yûsuf 'İzzet Pâşânın derhâl haberdâr edilmesi.

İsbû telgrâfın târîh-i vusûlünün iş'âr buyrulmasını ricâ ederim.

9-10/7/35

Mustafâ Kemâl

Üçüncü Ordu Müfettişî Erkân-ı Harbiye Re' îsi

Mîrâlây Kâzım ${ }^{8}$

${ }^{8}$ TİTE Arşivi, Kutu No: 296, Gömlek No: 18, Belge No: 18. 
MUSTAFA KEMAL PAŞA TARAFINDAN ALI FUAD PAŞAYA..... 235

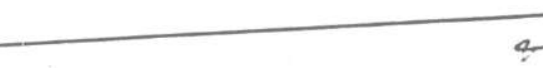

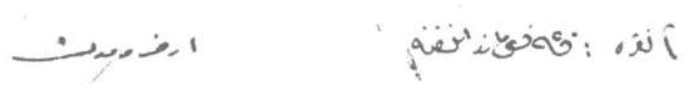

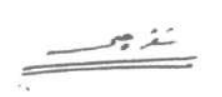

sevis";

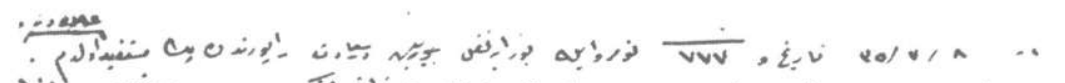

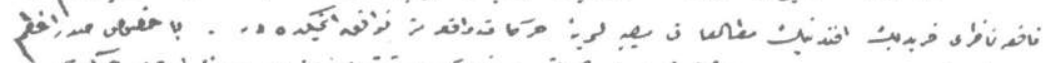

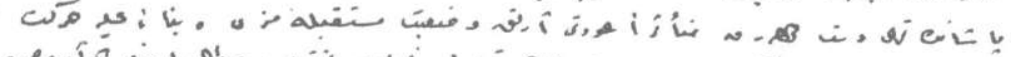

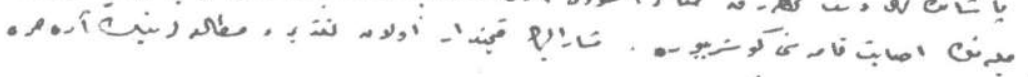

N: -

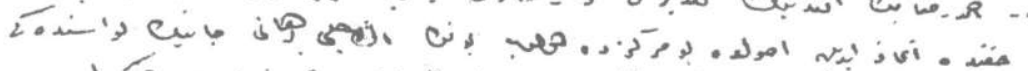

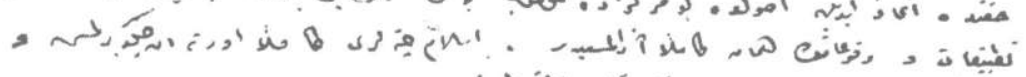

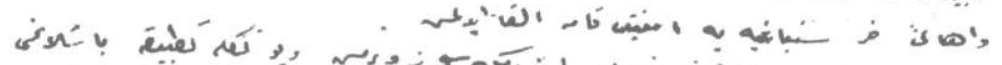

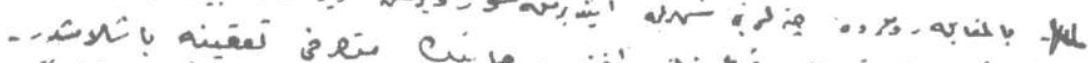

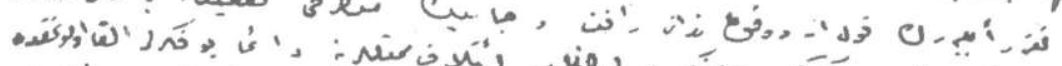

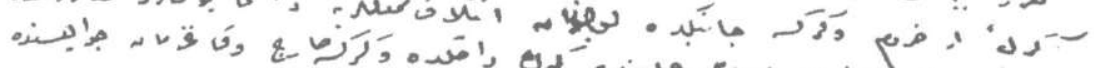

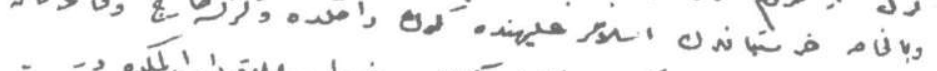

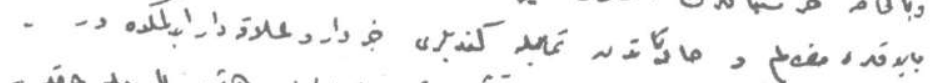

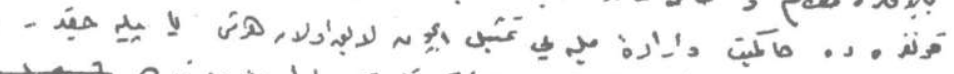

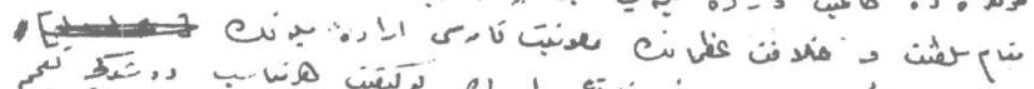

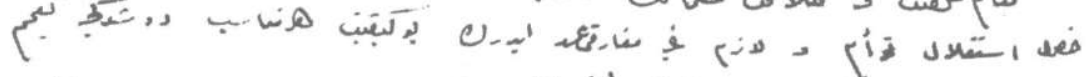

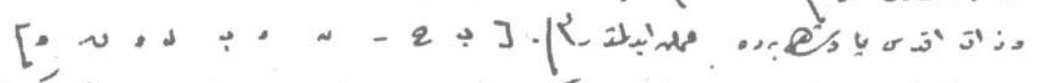

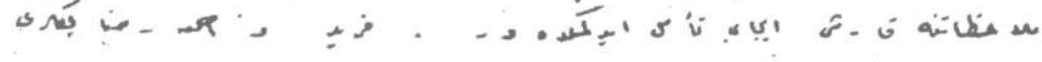
$\rightarrow$ is.

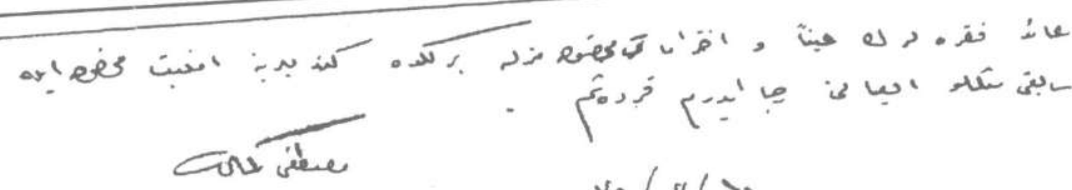

$$
\begin{aligned}
& \text { 2. } 10 / \cdots
\end{aligned}
$$

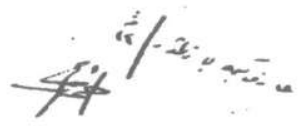


Şifre hâlli

Zâta mahsûsudur

Erzurum'dan

\section{Ankara: 20. K. Kumandanlı̆̆ına}

1-8/7/35 târîh ve 777 numro ile buraya nakil buyrulan Dersa'âdet raporundan pek müstefíd oldum. Nâfi'a Nâzırı Ferîd Beyefendinin mütâla'ât-ı musîbelerine harekât-ı vâkı'amız tevâfuk etmektedir. Bâ-husûs sadr-ı â'zam pâşânın tehî-dest olarak müte essiren 'avdeti artık vaz'iyet-i müstakîlemizi ve binâ'en-'aleyh hareketi milliyenin isâbet-i tâmmesini gösteriyor. Müşârun-ileyh kıymetdâr olan takdîr ve mütâla'alarının arasıra alınmast ve mahremâne îsâl buyrulmast.

2-Âhmed Rızâ Beyefendinin takdîrat ve irşâdât-ı 'alîyelerine 'arz-ı teşekkürat olunur. Gayr-i Müslimler hakkında ittihâz edilen usûl de bu merkezde olub bunun en celbi burhânî Cânîk Livâsı'ndaki tatbîkât ve vukû'âtın hemân kâmilen azalmasıdır. İslâm çeteleri kâmilen ortadan çekdirilmiş ve âhâlî-i Hristiyâniyeye emniyet-i tâmme ilkâ edilmiş.

Bil-mukâbile Rûmlar da çetelerini şehirlere indirmeğe söz vermiş ve bunula tatbîke başlanması takarrür eyleyerek Kolordu Kumandanı Re`fet, Cânîk mutasarrıfı ta 'kîbine başlamışdır. Gerek Erzurum ve gerekse Cânîk'de bulunan ìtilâf mümessillerine dâ'imâ bu fikirler ilkâ olunmakta ve bilhâssa Hristiyânlarin Íslâmlar 'aleyhinde gerek dahîlde ve gerekse hâriç ve Kağızman havâlîsinde yaptıkları mezâlîm ve hâdisâtdan tamâmıyla kendileri haberdâr ve 'alâkadar edilmektedir. Kongrede hâkimiyet ve irâde-i milliyeyi temsîl için layık olan her şey yapılacakdir.

Makâm-ı saltanat ve hilâfet-i 'uzmânın masûniyet-i tâmmesi irâde-i milliyenin husûl-i istiklâl tev'em ve lâzım-ı gayr-l müfârikî 'ad ederek bu keyfiyet her münâsib düşdükçe ta'mîm ve zât-ı akdes-i pâdişâhîye de 'arz edilmişdir.

3-[bhr $n v b l v k h]$ mülâhazâtına karşı icâbi te `mmül edilmekdedir. Ferîd ve Âhmed Rızâ Beyleri 'ầid fikraların 'aynen ve ihtirâmât-ı mahsûsamızla birlikte kendilerine emniyet-i mahsûsa ile sâbık-ı misüllü îsâlini ricâ ederim kardeşim. $10 / 7 / 35$

'Ârif Beye yazılmıştır. 12 Minh

Mustafâ $\mathrm{Kemâl}^{9}$

${ }^{9}$ TİTE Arşivi, Kutu No: 296, Gömlek No: 23, Belge No: 23. 


\section{4

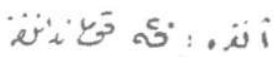

(2) - n

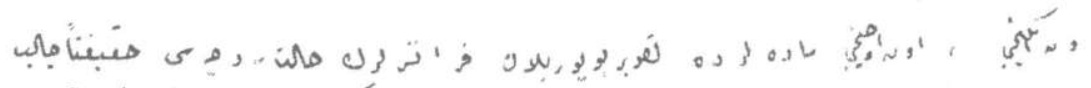

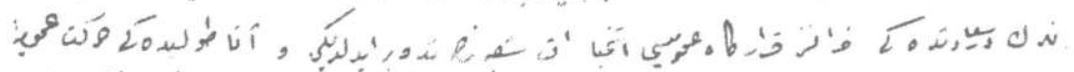

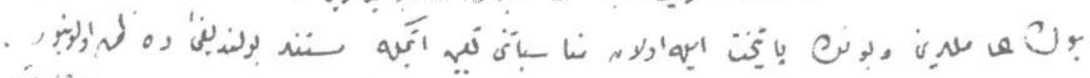

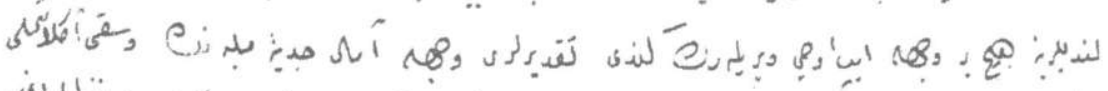

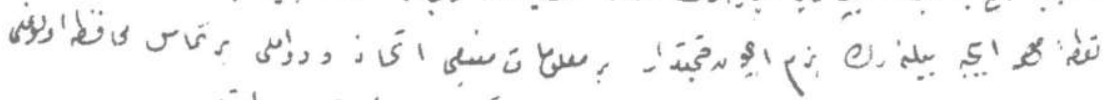

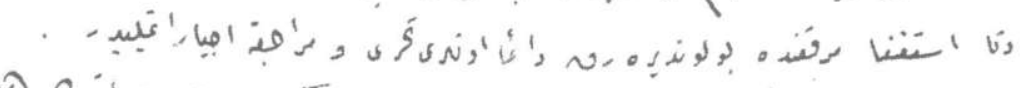

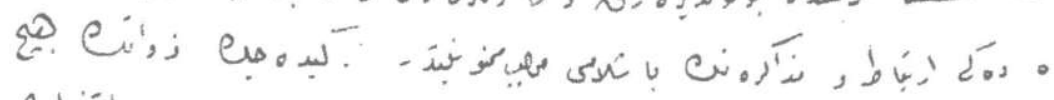

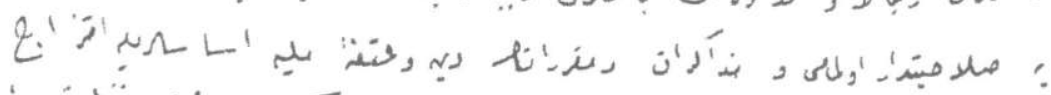

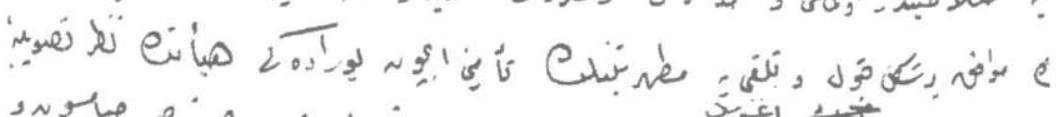

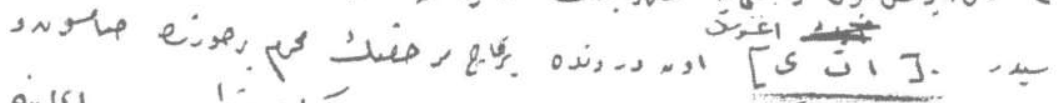

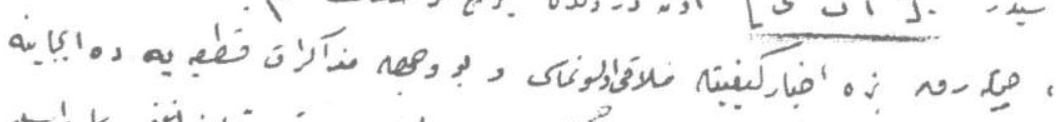

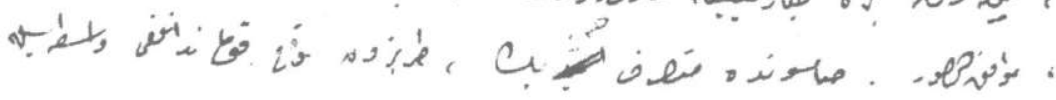

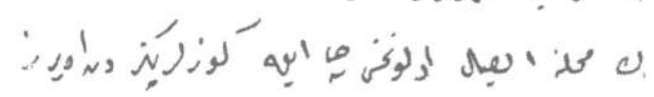

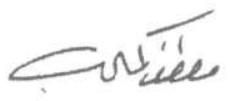

$$
\sum_{0}^{20}
$$


Sifre hâlli

Zâta mahsûsdur

Erzurum'dan

Ankara: 20. K. Kumandanlığına

C. 8/7/35 şifreye:

1-Onbirinci, Onikinci, Onüz̧üncü mâddelerde tasvîr buyurulan Fransızların hâlet-i rûhiyesi hakîkaten câlîb-i dikkatdir. Bunların Dersa'âdet'deki Fransız Karârgâh-l 'Umûmîsi İstihbârât Şu'besinden tedvîr eylediği ve Anadolu'daki hareket-i 'umûmîye-i milliyenin en büyük âmillerini ve bunun pây-i taht ile olan münâsebâtını ta'yîn etmeğe müstenid bulunduğu da zann olunuyor. Bunun için kendilerine hiçbir vechile ip ucu verilmeyerek kendi takdîrleri vechile amâl-i ciddiye-i milliyenin vüs'atı anlatmalı ve her hâlde bu nokta-i mahsûsa epeyce bilinerek bizim için kiymetdâr bir ma'lûmât menba'ı ittihâz ve devâmlı bir temâs-ı muhâfaza olunmalı ve kendimizi 'âdetâ istingâ mevki'inde bulundurarak dâ'imâ anları taharri ve mürâca'ata icbâr etmelidir.

2-On altıncı mâddede ki irtîbât ve müzâkerenin başlaması mûceb-i memnûniyetdir. Gidecek zevâtın hiçbir vechile imzâya selâhiyatdâr olmaması ve müzâkerât ve mukarrerâtın dîn ve 'atike-i milliye esâslarılya imtizâc ettirilerek en muvâfik bir şekil kabûl ve telakkîye mazhariyetinin te'mîni için buradaki hey'etin nazar-l tasvîbine iblâğı pek münâsibdir. [e t y] (ă̆ustosun) on dördünde birkaç murahhasın mahrem bir sûrette Samsun ve tercihen Trabzon'a çıkarak bize ihbâr keyfiyetiyle mülâkî olunmast ve bu vechile müzâkerât-ı kat'iyeye de icâbına tevessül olunmast da muvâfik olur. Samsun'da Mutasarrıf Hamîd Bey, Trabzon Mevki' Kumandanlı̆̆ vâsıtasıyla münâsib ve muvâsıla tè mîn olunur.

3-Bâlâdaki mevâdın mahâlline îsâl olunmast ricâ ile gözlerinizden öperiz.

11 Temmûz 35

'Ârif Beye yazılmıştır. 14 Minh

Mustafâ Kemâl ${ }^{10}$

${ }^{10}$ TITE Arşivi, Kutu No: 296, Gömlek No: 52, Belge No: 52. 


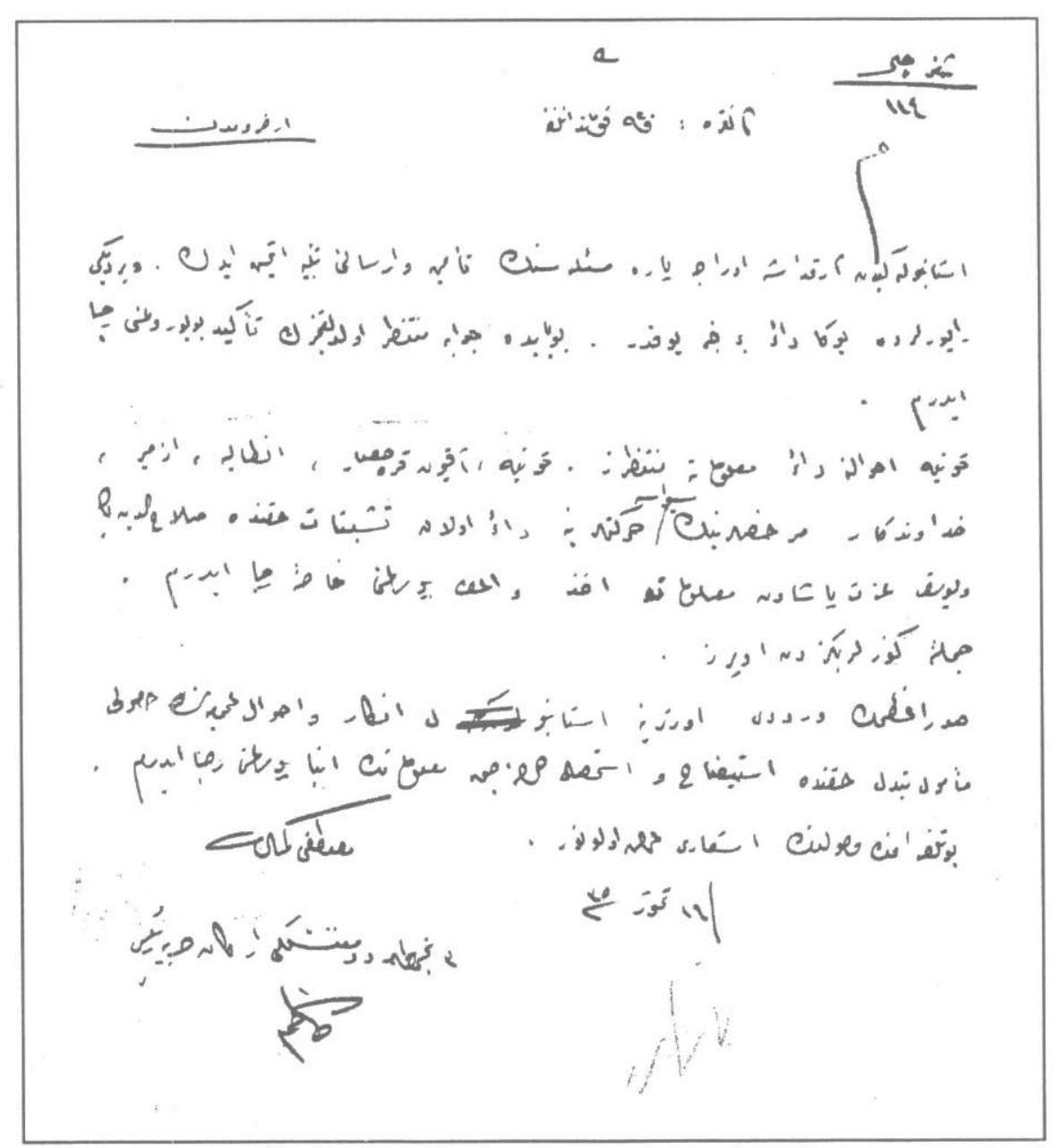


Şifre hâlli/114

Erzurum'dan

Ankara: 20. K. Kumandanlığına

İstânbûl'a giden arkadaşa oraca para mes'elesinin te'mîn ve irs'âlîni tenbih etmiş idik. Verdiği raporlarda buna dầir bir haber yoktur. Bu bâbda cevâba muntazır olduğumuzun te` kid buyrulmasını ricâ ederim.

Konya ahvâlîne dầir ma'lûmâta muntazırız. Konya, Afyonkarahisâr, Antalya, İzmîr, Hüdâvendigâr murahhaslarının Sivâs'a hareketlerine dâ'ir olan teşebbüsât hakkında Selâhaddîn Bey ve Yûsuf 'İzzet Pâşâdan ma'lûmât ahz ve i'tâ buyrulmasını hâsseten ricâ ederim. Cümleten gözlerinizden öperiz.

Sadr-1 â’zamın vürûdu üzerine İstânbûl efkâr ve âhvâl-i 'umûmîyesinde husûlü me`mûl tebeddül hakkında istîzâh ve istihsâl olunacak ma'lûmâtın inbâ verilmesini ricâ ederim. Bu telgrâfın vusûlünün iş'ârı 'arz olunur.

16 Temmûz 35

Mustafâ Kemâl

3. Ordu Müfettişliği Erkân-1 Harbiye Re`îsi

Mîrâlây Kâzım11

${ }^{11}$ TITE Arşivi, Kutu No: 296, Gömlek No: 60, Belge No: 60 . 